\title{
Patterns of Corporate External Financing
}

IN RECENT YEARS THE CORPORATE bond market has absorbed an unprecedented volume of new issues. Far from dwindling away under the pressure of equity kickers and short-term maturities, as many predicted in 1968 , net bond sales increased from a $\$ 12$ billion annual rate in the last half of 1969 to $\$ 30$ billion in the first half of this year. Several explanations for this upsurge have emphasized temporary factors, such as a sudden increase in desired liquidity following the Penn Central debacle and a catchup in bond issues that were delayed by tight money in 1969. But the continuing high level of bond issues raises questions that cannot be answered by resort to such transitory phenomena.

The rapid expansion of business financing needs has been matched by a pronounced rise in consumer saving rates. To an increasing extent savers and investors have become two separate groups; and the capital markets, as the primary means of transferring funds from one to the other, has grown substantially. These developments have raised some concern about the magnitude of the demands that will be placed upon the capital markets in future years; and, in particular, concern about the competitive position of other long-term securities, such as mortgages and state and local issues.

This paper examines some of the factors that have led to an expansion of business issues of corporate bonds and other marketable instruments. The set of financial decisions considered is a narrowly defined one that takes as predetermined the firm's production and investment decisions and the re- 
sulting flow of profit income. ${ }^{1}$ Thus, the primary concern is with the composition rather than the scale of the external financial needs.

\section{Long-term Trends}

A condensed table of the sources and uses of funds by nonfinancial corporations for the period 1956-70 is shown in Table 1. The explosive increase in external financing in 1966-70 is particularly evident in comparison with earlier periods. The proportion of total capital outlays financed by internal funds declined from 91 percent in the 1961-65 period to 75 percent in 196670. To some extent this is the expected result of what might be termed an unusually long ten-year business cycle, with capital outlays responding more slowly than internal funds to cyclical variations in economic activity. But the natural disparity between the two periods was magnified by several reductions in corporate taxes in 1961-65 and an unusually strong expansion of capital outlays in recent years. In addition, capital consumption allowances have lagged behind replacement demand during the recent period of inflation, resulting in higher reported profits and thus higher tax payments.

Trade and consumer credit are two other uses of funds that are not easily controllable in the short run. These two uses, together with the difference between capital outlays and internal funds, give rise to the external financing deficit shown in the table. Firms must meet this financing deficit by a combination of reductions in liquid asset balances, additional short-term debt, and additional long-term financing in the form of new bond and stock issues and mortgages.

Liquid assets increased substantially throughout the 1960s. All of the growth was concentrated in interest-yielding time deposits and marketable securities. Money balances actually declined over the period as a whole despite the substantial growth in the level of transactions. Thus, at least in the long run, the growth of liquidity reserves has required substantial additional borrowing.

Short-term debt accounted for about one-third of external borrowing. Throughout the postwar period until 1966, nearly all of this credit was ob-

1. This does not imply that production and investment decisions are not influenced by interest rates and the structure of the financial balance sheet. Rather, the subject of the analysis presented here should be viewed as a subset of a wider set of interrelated decisions by the firm. 
Table 1. Sources and Uses of Funds, Nonfinancial Corporations, Selected Periods, 1956-70

Billions of dollars

\begin{tabular}{|c|c|c|c|c|c|c|}
\hline \multirow[b]{2}{*}{ Type of fund } & \multicolumn{2}{|c|}{$1956-60$} & \multicolumn{2}{|c|}{$1961-65$} & \multicolumn{2}{|c|}{ 1966-70 } \\
\hline & Use & Source & Use & Source & Use & Source \\
\hline Gross internal funds & & 158.4 & & 228.4 & & 305.4 \\
\hline Capital expenditures ${ }^{a}$ & 182.5 & $\ldots$ & 252.1 & $\ldots$ & 406.2 & $\ldots$ \\
\hline Net nonfinancial uses & 24.1 & & 23.7 & & 100.8 & \\
\hline Change in unpaid tax liability & & -6.5 & & 6.6 & $\ldots$ & -7.6 \\
\hline Net trade credit & 15.0 & $\ldots$ & 21.4 & $\ldots$ & 8.4 & $\ldots$ \\
\hline Consumer credit & 2.6 & ... & 4.4 & ... & 6.5 & ... \\
\hline External financing deficit & 48.2 & $\ldots$ & 42.9 & $\ldots$ & 123.3 & $\ldots$ \\
\hline Liquid asset accumulation & 0.6 & $\ldots$ & 14.7 & $\ldots$ & 22.8 & $\ldots$ \\
\hline Short-term debt & $\ldots$ & 13.6 & $\ldots$ & 23.4 & $\ldots$ & 53.0 \\
\hline Bank loans & $\ldots$ & 11.7 & $\ldots$ & 22.0 & $\ldots$ & 35.3 \\
\hline Otherb & $\ldots$ & 1.9 & $\ldots$ & 1.4 & $\ldots$ & 17.7 \\
\hline Long-term financing & $\ldots$ & 44.3 & $\ldots$ & 47.5 & $\ldots$ & 108.6 \\
\hline Bonds & $\ldots$ & 22.0 & $\ldots$ & 22.5 & $\ldots$ & 70.2 \\
\hline Stocks & $\ldots$ & 10.6 & $\ldots$ & 4.2 & $\ldots$ & 13.8 \\
\hline Mortgages & $\ldots$ & 11.7 & $\ldots$ & 20.8 & $\ldots$ & 24.6 \\
\hline Net miscellaneous liabilities & 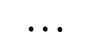 & 11.9 & & 13.7 & & 16.1 \\
\hline Statistical discrepancy & 21.0 & $\cdots$ & 27.0 & $\cdots$ & 31.6 & 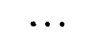 \\
\hline Total & 221.7 & 221.7 & 319.6 & 319.6 & 475.5 & 475.5 \\
\hline
\end{tabular}

Sources: Board of Governors of the Federal Reserve System, Division of Research and Statistics, Flow of Funds Accounts, 1945-68 (1970), and "Flow of Funds, Seasonally Adjusted, 2nd Quarter, 1971, Preliminary" (1971; processed).

a. Defined as capital expenditures inclusive of foreign investment.

b. Open market paper plus finance company loans.

tained from commercial banks. But in the last five years, as banks have found it increasingly difficult to finance all the credit demands, corporations have gone directly to the market with issues of open market paper. About half of the nonbank financing has been channeled through finance companies, which in turn have issued their own commercial paper.

In flow terms the mix of financing between short- and long-term credit did not change significantly in 1966-70 in comparison with the first half of the decade; the expansion in both was primarily the result of the increased size of the total deficit. Bond financing continued to be by far the largest source of long-term funds. Mortgage borrowing relative to investment in structures declined in the latter half of the 1960s. Stock financing was more substantial in the last half of the decade but still represented only about 10 percent of long-term debt sources. 
The last two rows in Table 1 show net miscellaneous liabilities and the statistical discrepancy. The first includes unallocated assets and liabilities and minor accounts, such as insurance receivables, foreign currency holdings, government loans, and so on. The sizable statistical discrepancy arises from the combining of the national income accounts with data from financial balance sheets reported to other government agencies, primarily the Internal Revenue Service (IRS). The major portion of this discrepancy is thought to represent the exclusion from the capital expenditures data of the purchase of land and used capital goods from other sectors and a persistently lower estimate of inventory accumulation in the national income accounts relative to the IRS data. Although there are major discrepancies in the estimates of trade credit and trade debt, they typically result in an overstatement of reported assets relative to liabilities rather than the reverse; therefore, the true discrepancy may be even larger than that shown in the flow-of-funds data.

\section{Cyclical Patterns}

The historical pattern of short-term changes in the financing deficit and the major financial flows is shown in Figure 1. The deficit itself has a pronounced tendency to lag behind the general business cycle, with the major increases occurring in the late stages of expansion. In part this reflects the lag in fixed capital outlays. While paralleling the long-term growth of capital expenditures, internal funds have a larger short-run variance, with the most rapid growth occurring in the early stages of recovery. The cycle in inventory accumulation tends to offset that of retained earnings as well as to introduce a strong irregular component.

Liquid assets exhibit the largest cyclical fluctuations of the major financial items, with the peaks occurring in the very early stages of a recovery. ${ }^{2}$ Short-term borrowing also has a strong cyclical component but the peaks are substantially later in the cycle and such loans have a smaller period-toperiod variability.

2. The liquid asset series used here includes the miscellaneous assets category of the flow of funds. This is done because of substantial problems of measuring liquid assets in the short run and accurately distinguishing between deposits of households and business at commercial banks. As a result of overall control totals in the basic data sources, errors in measuring liquid assets will be reflected in the residual miscellaneous asset category. 
Figure 1. Composition of External Finance, Nonfinancial Corporations, Semiannual Flows, 1955-71

Billions of dollars

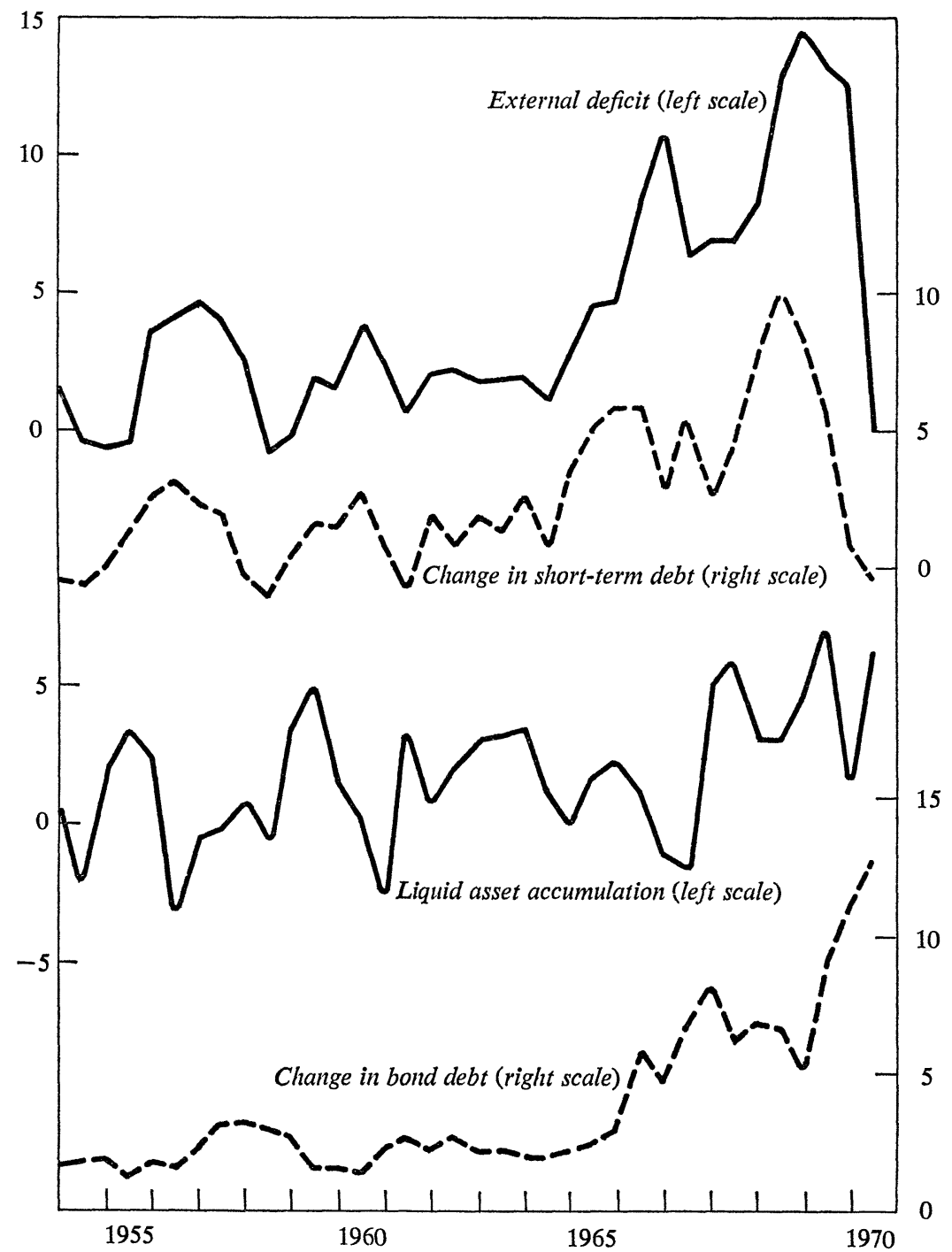

Source: Unpublished quarterly flows from the Board of Governors of the Federal Reserve System, Division of Research and Statistics. 
A comparison of the patterns of short-term reserves (liquid assets minus short-term debt) and of the external deficit reveals that firms have normally built up their liquidity reserve during periods of recovery and drawn it down in the late stages of the cycle. While reducing the cyclical volatility of the external deficit, this behavior has left a substantial residual to be financed by longer-term financing.

Net bond issues, the major long-term source of funds, have relatively low correlation with short-term movements in the external deficit, and limited period-to-period variability. Among the items not shown separately, net issues of corporate stock paralleled the rapid rise of bond issues; but they are dominated in the short run by individual issues. Mortgage loans show a pattern different from that of other long-term debt because of their close tie to residential and nonresidential construction. They varied modestly in the short run, but declined significantly in tight money periods.

In the remainder of this paper a simple statistical model of business financing is used to examine the pattern of corporate borrowing in recent years. The results suggest that the current high level of corporate bond issues is primarily a result of an unusually high external deficit and a postponement of bond issues from previous tight money periods.

\section{The Data}

\section{BASIC SOURCES}

The data for this study were obtained from the nonfinancial corporations sector of the flow-of-funds tables, published by the Board of Governors of the Federal Reserve System. On the income and expenditure side, they are consistent with the national income accounts and incorporate the July 1971 revisions.

However, the data here differ in several respects from the published tables. First, all of the series are seasonally adjusted by applying a multiplicative seasonal to the data in stock form. These levels were obtained by cumulating the quarterly flows. The cumulative sum of the flows was used rather than the published stocks as a means of minimizing the impact of frequent accounting changes in the basic data. This method also excludes from the series unrealized capital gains and losses on corporate stock (they are included in the published data on levels but not in the flows). The pub- 
lished seasonally adjusted data also use forcing factors to insure that the seasonals balance out for all assets and sectors of the total flow-of-funds matrix. Although desirable on other grounds, this method introduces some irregularities into individual series that it was desirable to avoid.

Second, because of a strong overall growth trend, the individual series are examined in terms of semiannual flows rather than stocks, in order to highlight the cyclical patterns. Semiannual data offer several advantages over quarterly data. Because of limitations in the basic data, they are more reliable and have a smaller component of random measurement error. The longer measurement period also reduces the complexity of behavioral decision lags in adjusting stocks to desired levels, an area in which existing statistical estimation techniques are most inadequate. Of course, some timing detail is lost and offsetting estimation problems may be introduced for activities whose basic decision period is less than six months. But, on the whole, the six-month interval more clearly highlights the basic cyclical trends under consideration here.

\section{ORGANIZATION OF THE DATA}

The various sources of financing shown in Table 1 were grouped into several major categories, which were convenient for examining the determinants of the composition of financial balance sheets. Three major financing sources can be readily identified: long-term securities, short-term loans, and reduced liquid assets.

The remaining balance sheet items are net trade credit, miscellaneous liabilities, and the statistical discrepancy. The first is measured with a substantial error in the aggregate that makes its short-run movements difficult to interpret. The second is the residual from subtracting various known individual items from total liabilities.

One approach would be to aggregate these three items and deduct them from the external deficit. While such a procedure would maintain the overall constraint for the three major financing items-liquid assets, short-term loans, and long-term debt-it makes it difficult to give meaning to the deficit itself. It also introduces more serious statistical problems since errors in measuring the components will be reflected in this residual category, producing a correlation between the error term and an independent variable in any regression procedure. Instead, this has been left as a residual category; the equations for liquid assets, and short- and long-term debt, were 
estimated directly, and the implied structure of the residual equation was used as a check on the specification of the others.

Finally, after some preliminary experimentation, business mortgage debt was excluded from the analysis and subtracted from the deficit itself. The determinants of this type of financing are substantially different from those of the other financial items. Closely tied to the purchase of structures, it does not serve as a general source of finance. In addition, it is difficult to obtain an accurate measure of the effective interest rate because of the importance of components of the total financing costs other than nominal contract rates. Its inclusion in the model as a source of funds for general purposes appears to be an unnecessary complication.

The basic financial identity on which the empirical section focuses can be explicitly defined as follows:

$$
E X-\triangle T X P B=\Delta S L+\triangle B N D+\triangle S T K-\triangle L A+\triangle O L,
$$

where

$$
\begin{aligned}
E X= & \text { total capital outlays }+ \text { foreign direct investment }+ \text { change in } \\
& \text { consumer credit assets }- \text { gross internal funds }- \text { change in } \\
& \text { mortgage liabilities } \\
T X P B= & \text { unpaid tax liabilities } \\
S L= & \text { bank loans }+ \text { open market paper }+ \text { finance company loans } \\
B N D= & \text { corporate bonds } \\
S T K= & \text { corporate stock } \\
L A= & \text { liquid assets (see footnote } 2) \\
O L= & \text { net trade debt }+ \text { miscellaneous liabilities }+ \text { statistical dis- } \\
& \text { crepancy. }
\end{aligned}
$$

In managing its debt position the firm is faced with a given external deficit, as defined by the first term on the left-hand side of the above identity, that must be covered by some combination of changes in liquid assets, short-term debt, long-term bonds, stock issues, and miscellaneous liabilities. The final category is identified primarily as a means of minimizing statistical problems and is not viewed as a fifth category over which the firm can actively exercise control. Therefore, there are actually four basic financing sources, which involve three independent decisions. Unpaid tax liabilities are treated as a separate predetermined flow in the statistical presentation because of their relatively strong impact on liquid assets. This distinction is ignored in the outline of the basic analytical framework that follows. 
The following sections seek to examine the use of these balance sheet items by developing statistical equations that illustrate the role of the major determinants of the debt management decision.

\section{Basic Concepts}

The analytical framework for examining the composition of external financing draws heavily on a previous study of manufacturing firms by W. H. L. Anderson covering the period 1948-60, and a recent book by Gordon Donaldson. ${ }^{3}$ In fact, one of the purposes of this analysis is to determine whether a relatively simple financial model, which was quite successful in explaining earlier behavior, is consistent with the pattern of financing observed in recent years.

The firm is viewed as having predetermined production and investment plans that, together with unforeseen events, give rise to a predetermined outflow of funds. Set against this are the firm's internal sources of funds. The analysis here relies on the conclusion of several previous studies that dividend policies are not significantly influenced by current financing needs, and uses cash flow net of dividends as the basic measure of this flow. The firm's funds deficit is taken as the difference between its capital outlays and internal funds plus the net changes in several financial accounts over which the firm has only limited control-consumer credit, mortgage debt, and unpaid tax liabilities. The firm must finance this flow with a combination of bond and stock issues, short-term loans, and reduced holdings of liquid financial assets.

The essence of the financial decision is contained in the uncertainty attached to these future financing needs. The desire to finance current needs at minimal costs is tempered by a desire to maintain flexibility with regard to the firm's ability to meet future needs and opportunities. The desire for flexibility is reflected in the holding of a reserve of uncommitted financial resources. These resources take the form of ownership of liquid financial assets, an unused line of bank credit, and a margin of debt capacity above current use. ${ }^{4}$ This goal of flexibility in the financial structure

3. W. H. Locke Anderson, Corporate Finance and Fixed Investment: An Econometric Study (Harvard University Press, 1964); and Gordon Donaldson, Strategy for Financial Mobility (Harvard University Press, 1969).

4. The concept of debt capacity is measured in terms of the firm's ability to finance its debt out of current income and the increasing pressure upon the firm to use equity issues as the stock of outstanding debt rises relative to its cash flow. 
may result in substantial departures of behavior from a pattern that would be optimal in terms of strict maximization of the stockholders' current wealth.

\section{SHORT- VERSUS LONG-TERM FINANCING}

The ability of firms to meet near-term fluctuations in financial requirements-what is sometimes called liquidity-is defined here as the sum of liquid financial assets plus the unused portion of short-term debt capacity. This definition would seem more relevant to normal decision making than measures, such as the quick ratio (cash plus government securities divided by current liabilities), that are related more closely to crisis situations of bankruptcy or liquidation of the firm. The liquidity decision is primarily a choice between long- and short-term financing, since for any given external deficit liquidity can be increased only at the cost of incurring additional long-term debt.

The two forms of financing, however, are not perfect substitutes for one another. Normally, long-term debt is not as immediately available and carries a higher nominal interest charge. Since the firm does not obtain a yield on financial assets equal to the cost of borrowing, the issuance of excessive amounts of long-term debt matched by a surplus of liquidity will involve additional finance charges. Furthermore, the substantial economies of scale in security flotation make this type of financing most practical on a periodic basis.

On the other hand, long-term debt does offer major advantages over the maintenance of a low level of short-term reserves. By obtaining long-term financial commitments, the firm can avoid the uncertainty of both cost and availability associated with continuous refinancing of its debt. Thus, any costs must be balanced against the increase in liquidity and reduction in risk that the lengthening of the debt structure provides. In addition, by concentrating its unused debt capacity in the short market, the firm can more readily respond to sudden changes in its financing needs.

The firm normally can be expected to have some basic notions about the future size and variation in its external deficit. At the one extreme it could attempt to provide for the maximum likely deficit through long-term debt issues, and hold temporary excess balances in the form of liquid assets. Alternatively, it could meet all of its external deficit at each point in time with short-term debt. The more likely outcome will lie somewhere between 
these two extremes. The precise choice will depend upon the variability and predictability of the external deficit, the cost and availability of short- and long-term debt, and the balancing of lower finance charges against increased risk on refinancing.

The composition of the financial balance sheet between long and short debt is a matter of concern not only to the firm but also to lending institutions and bond rating agencies. In a market in which a large portion of credit is obtained through individual negotiations with lenders, these institutions can and do exercise strong pressures on firms to refinance continuing deficits through long-term issues.

Finally, firms may be sensitive in their timing of long-term financing to the level of current interest rates relative to their expected future values. That is, they may play a speculative game of accepting a low level of current short-term liquidity in the expectation of lower bond rates in the future. However, their flexibility in this regard is limited by the increased near-term risk of being unable to finance a sudden increase in the external deficit.

Financial liquidity in several respects functions like physical inventory stocks in that it acts as a buffer against unanticipated variations in the external deficit and provides the firm with the ability to optimize its long-term debt issues with respect to both timing and relative cost considerations.

This behavior can be described formally by specifying a desired level of liquidity for any period that depends on the anticipated deficit $\left(E X^{e}\right)$, relative interest rates $\left(r_{S}-r_{L}\right)$, a measure of the difference between the current and expected future costs of long-term financing $\left(r_{L}-r_{L}^{e}\right)$, and preexisting levels of liquidity $\left(L I Q_{-1}\right)$, long-term debt $\left(L D B T_{-1}\right)$, and debt capacity $\left(L D B T^{c}\right)$ :

$$
L I Q^{*}=f\left(E X^{e}, r_{S}-r_{L}, r_{L}-r_{L}^{e}, L I Q_{-1}, L D B T_{-1}, L D B T^{\circ}\right) .
$$

The actual change in liquidity will then be the sum of two distinct components: a desired increase as reflected in the above relationship, and an unanticipated component due to errors in the projection of the deficit:

$$
\Delta L I Q_{t}=\Delta L I Q_{t}^{*}+b\left(E X_{t}^{e}-E X_{t}\right) .
$$

Since there is a single degree of freedom in this simplified financial decision, a similar equation suffices for long-term financing except that the coefficient of the surprise term in the deficit should be $(1-b)$ and the coefficients on the interest rate terms are opposite in sign. 


\section{THE COMPOSITION OF SHORT-TERM RESERVES}

According to this measure of liquidity, the firm can provide for any given level of short-term reserves either by holding a combination of high liquid assets and corresponding high levels of short-term debt, or by combining low liquid assets with ready availability of additional short-term credit:

$$
L I Q=L A+\left(S L^{*}-S L\right)
$$

where $L A$ is liquid assets, and $\left(S L^{*}-S L\right)$ is unused short-term debt capacity.

In comparison with long-term debt, liquid assets, bank loans, and open market paper can be drawn on relatively quickly, but they differ among themselves in the degree of availability and nominal costs. Directly owned financial reserves are more surely available than is a line of bank credit. However, since borrowing rates typically exceed lending rates, a given short-term reserve composed of a large amount of liquid assets together with high levels of bank lending is more expensive than one composed of a small amount of assets and low utilization of bank lending.

To the extent that short-term credit consists primarily of bank loans, there may be some difficulty in measuring the costs of such credit. In addition to the nominal rates, banks may vary nonrate terms, such as compensating balances and credit standards. Thus, the loan rate may be an inadequate measure of loan costs if changes in such nonrate items are not proportionate to changes in the rate itself. In order to allow for such an eventuality several proxy measures of nonprice rationing are included.

The major difficulty in reflecting these factors in an empirical description of the financial structure comes in defining "desired liquidity" and "debt capacity." For the individual firm, liquidity should be related to the expected size of future deficits, the uncertainty connected with these expectations, and the magnitude of everyday transactions. At the aggregate level this relationship is rather fuzzy, but an attempt is made here to approximate it by scale variables such as sales and total liabilities.

The primary limitation on debt capacity ought to be the firm's ability to service the debt out of its existing cash flow. Given the uncertainty of future credit conditions, this capacity is greater when the debt consists primarily of long- rather than short-term obligations. In addition to cost considerations, the mix of debt should be related to whether the deficit is likely to continue or is simply cyclical in nature.

The mix of financing between debt and equity issues is not the focus here. 
Current research in this area has been dominated by a hypothesis put forth by Modigliani and Miller that in the absence of tax advantages the firm's overall cost of capital is independent of its debt-equity structure. ${ }^{5}$ The resulting controversy and empirical work have centered on the choice between debt and equity issues, and less attention has been devoted to the related question of the mix between long- and short-term financing. Yet, it is the latter decision that exhibits a greater cyclical fluctuation and that has important implications for both the structure of market interest rates and the role of financial intermediaries in the capital markets.

While the issue is of importance for determining the total size of the capital budget, it is not of dominant concern in examining the composition of external financing and its impact on the capital markets. The debt-equity mix has not been a major source of cyclical variability. New issues of stock are most common for small firms with no close correspondence to the overall business sector. The short-run pattern is dominated by individual issues and frequently responds to the degree of merger activity among major firms. However, in the last two years, major firms have turned increasingly to stock issues as a source of funds. While the experience is yet too new to be fully incorporated in a simple time series model, it does suggest that the magnitude of the external deficit of recent years is exerting significant pressure on the financing capabilities of some firms.

The model can be summarized as an attempt by firms to maintain a desired proportion of the cumulative sum of past external deficits, $K E X$, in the form of long-term debt. This desired ratio should rise as short-term rates increase relative to long-term rates, and fall if the current long-term rate is above the expected future rate. It should be positively associated with internal funds, $R E$, as a measure of ability to finance additional debt.

$$
\frac{L D B T^{*}}{K E X_{-1}}=m_{0}+m_{1}\left(r_{S}-r_{L}\right)+m_{2}\left(r_{L}-r_{L}^{e}\right)+m_{3} t+m_{4} \frac{R E}{K E X_{-1}} .
$$

A trend term, $t$, is included in all of the desired stock formulations to insure that the interest rates do not pick up other secular influences on the

5. Franco Modigliani and Merton H. Miller, "The Cost of Capital, Corporation Finance, and the Theory of Investment," American Economic Review, Vol. 48 (June 1958), pp. 261-97. Although there can be little question about the validity of the Modigliani-Miller hypothesis in its theoretical form, its relevancy to real decisions is more doubtful. The recognition of imperfect capital markets with transaction costs; differential tax treatment of interest, dividend, and capital gains income; and nonsymmetric risk distributions (for example, risk of bankruptcy) implies that financial decisions will influence the value of the firm. 
desired stocks. The high level of collinearity makes it impossible to include separate interest rates for financial assets, short-term loans, and bonds. Therefore, only the two extremes of a short rate and long rate were included. These are measured by the three-month Treasury bill rate and the Baa bond yield. Multiplying this equation through by the accumulated sum of the deficit yields an equation in which the interest rate and trend terms are all scaled by the size of the cumulated deficit. Another constant term is added to this form to insure that the statistical requirement of a zero mean for the error term is satisfied. Since firms cannot be expected instantaneously to eliminate any discrepancy between the desired and actual debt position as the total deficit changes, the estimated equation also allows for a partial adjustment of the gap between the desired and actual debt:

$$
\triangle L D B T=g\left[L D B T^{*}-L D B T_{-1}\right] \text {, }
$$

or

$$
\Delta L D B T=a_{0}+g\left[b_{0}+b_{1} r_{S}+b_{2} r_{L}+b_{3} t\right] K E X_{-1}-g L D B T_{-1}+b_{4} R E .
$$

The major difference between the equations for long-term debt and those for liquidity is that the former will respond hardly at all to variations in the current deficit. Thus the liquid asset and short-term debt equations should be similar in structure to that for long-term financing, except for the addition of a strong response to changes in the current deficit. The transitory nature of the deficit in the short run, together with delays associated with bond issues, should imply that current financing needs will be absorbed largely by short-term loans and liquid assets.

$$
\begin{gathered}
\Delta L A=g^{\prime}\left[L A^{*}-L A_{-1}\right]+c^{\prime}(E X) \\
\Delta S L=g^{\prime \prime}\left[S L^{*}-S L_{-1}\right]+c^{\prime \prime}(E X),
\end{gathered}
$$

or

$$
\begin{aligned}
\Delta L A= & a_{0}^{\prime}+g^{\prime}\left[b_{0}^{\prime}+b_{1}^{\prime} r_{S}+b_{2}^{\prime} r_{L}+b_{3}^{\prime} t\right] K E X_{-1} \\
& -g^{\prime} L A_{-1}+b_{4}^{\prime} R E+c^{\prime} E X \\
\Delta S L= & a_{0}^{\prime \prime}+g^{\prime \prime}\left[b_{0}^{\prime \prime}+b_{1}^{\prime \prime} r_{S}+b_{2}^{\prime \prime} r_{L}+b_{3}^{\prime \prime} t\right] K E X_{-1} \\
& -g^{\prime \prime} S L_{-1}+b_{4}^{\prime \prime} R E+c^{\prime \prime} E X .
\end{aligned}
$$

\section{Statistical Findings}

Illustrative regression equations for the major categories of the financial balance sheet are shown in Table 2. Each of the equations was estimated by ordinary least squares for semiannual observations over the period 1954-70: 
Table 2. Coefficients for Financial Equations, Semiannually, 1954-70

\begin{tabular}{|c|c|c|c|c|}
\hline \multirow[b]{2}{*}{ Independent variable } & \multicolumn{4}{|c|}{ Equation } \\
\hline & $\begin{array}{l}\text { Increase in } \\
\text { bonds }\end{array}$ & $\begin{array}{l}\text { Stock } \\
\text { issues }\end{array}$ & $\begin{array}{l}\text { Increase in } \\
\text { short-term } \\
\text { debt }\end{array}$ & $\begin{array}{l}\text { Increase in } \\
\text { liquid } \\
\text { assets }\end{array}$ \\
\hline Current deficit & $\cdots$ & $\cdots$ & $\begin{array}{l}0.461 \\
(5.4)\end{array}$ & $\begin{array}{l}-0.681 \\
(10.5)\end{array}$ \\
\hline Unpaid tax liabilities & $\cdots$ & $\cdots$ & $\cdots$ & $\begin{array}{c}0.68 \\
(8.0)\end{array}$ \\
\hline Corporate stock retirements & $\begin{array}{l}0.413 \\
(5.1)\end{array}$ & $\cdots$ & $\begin{array}{l}0.672 \\
(3.9)\end{array}$ & $\cdots$ \\
\hline Lagged own stock & $\begin{array}{l}-0.416 \\
(8.3)\end{array}$ & $\begin{array}{l}-0.286 \\
(6.7)\end{array}$ & $\begin{array}{l}-0.395 \\
(4.3)\end{array}$ & $\begin{array}{c}-0.418 \\
(8.0)\end{array}$ \\
\hline Cumulated deficit ${ }^{b}$ & $\begin{array}{l}0.200 \\
(6.2)\end{array}$ & $\begin{array}{c}0.042 \\
(6.25)\end{array}$ & $\begin{array}{l}0.161 \\
(2.0)\end{array}$ & $\begin{array}{l}-0.421 \\
(4.3)\end{array}$ \\
\hline Bill rate ${ }^{\circ}$ & $\begin{array}{l}-0.010^{d} \\
(6.0)\end{array}$ & $\ldots$ & $\begin{array}{l}0.025 \\
(7.4)\end{array}$ & $\begin{array}{l}0.031 \\
(8.2)\end{array}$ \\
\hline Bond rate ${ }^{c}$ & .. & $\cdots$ & $\begin{array}{l}-0.048 \\
(5.8)\end{array}$ & $\begin{array}{l}-0.018 \\
(4.5)\end{array}$ \\
\hline Time $^{\circ}$ & $\begin{array}{l}0.002 \\
(4.8)\end{array}$ & $\begin{array}{l}0.002 \\
(3.1)\end{array}$ & $\begin{array}{l}0.005 \\
(4.8)\end{array}$ & $\begin{array}{l}0.007 \\
(6.4)\end{array}$ \\
\hline Stock of physical assets ${ }^{\ominus}$ & $\begin{array}{l}0.065 \\
(3.2)\end{array}$ & $\ldots$ & $\cdots$ & $\ldots$ \\
\hline Internal funds & $\begin{array}{l}0.252 \\
(4.0)\end{array}$ & $\begin{array}{l}-0.089 \\
(2.0)\end{array}$ & $\cdots$ & $\cdots$ \\
\hline Dividend-price yield & $\cdots$ & $\begin{array}{l}-0.011^{d} \\
(4.0)\end{array}$ & $\cdots$ & $\cdots$ \\
\hline Constant & $\begin{array}{l}2.217 \\
(1.5)\end{array}$ & $\begin{array}{l}46.452 \\
(6.9)\end{array}$ & $\begin{array}{l}5.106 \\
(3.2)\end{array}$ & $\begin{array}{l}34.623 \\
(6.8)\end{array}$ \\
\hline $\bar{R}^{2}$ & 0.98 & 0.84 & 0.92 & 0.87 \\
\hline $\begin{array}{l}\text { Standard error of estimate } \\
\text { (billions of dollars) }\end{array}$ & 0.37 & 0.35 & 0.74 & 0.82 \\
\hline
\end{tabular}

Source: Calculated by the author from unpublished quarterly flows from the Federal Reserve System. a. All data are seasonally adjusted. The numbers in parentheses are $t$-statistics.

b. Cumulative sum of external deficit. Since this variable is used as a scale factor for interest rates and the trend, its net impact on the dependent variable can be evaluated only in terms of all four coefficients.

c. Scaled by the net stock of financial liabilities. Bill rate is for three-month Treasury bills; bond rate is Baa rate; time is a quarterly trend with $1950: 1=1.0$.

d. Average of current and previous periods with weights of 0.6 and 0.4 , respectively.

e. Cumulative sum of fixed investment less capital consumption allowance.

Although demand equations are estimated for four basic items in the balance statement, it must be emphasized that there are only three independent decisions that can be made within the balance sheet constraint. The estimation of all four equations is intended to provide some check on the reasonableness of the overall model. The fact that there is a fifth residual category results from the treatment of the statistical problems of measurement error rather than implying another category of financing. 


\section{LONG-TERM FINANCING}

Bond issues were found to be dominated by an attempt to maintain a stable proportion of bonds to total financial liabilities in the long run. They appear to have no significant correlation with current variations in the external deficit. The influence of internal funds in the bond equation is consistent with the view that debt capacity is limited by the ability to service the debt out of current income. The net stock of physical assets was added to the equation as a better means of measuring the desired stock. It is significant primarily because of its greater short-run stability compared with the cumulative sum of the total deficit.

Bond issues were not sensitive to relative rate differentials with respect to short-term rates or the dividend-price ratio. Instead the dominant effect in tight money periods, as measured by a high short-term interest rate, seems to be postponement of issues. Attempts were made to use a weighted average of past interest rates as a more elaborate measure of an expected or normal rate, but it was highly collinear with the time trend and contributed nothing to the fit of the equation. The trend itself might be viewed as reflecting some aspects of rate expectations.

Variations in bond issues were affected in recent years by abnormally high corporate stock retirements associated with merger activity (particularly in the period from 1967 through the first half of 1969). A substantial proportion of these retirements was financed by bond issues and bank loans. In an attempt to reduce the distortions these developments may have introduced, stock retirements were added to the bond and short-term debt equations as a proxy for these exchanges. The volume of gross new issues is then the measure of corporate stock used in the second equation.

As was the case with bonds, new stock issues have very little correlation with the magnitude of the current deficit. Internal funds are given some support as a measure of debt capacity in the bond equation by their negative impact on new stock issues. Interest rates were not significant, but there is some evidence that low stock prices (as reflected in high dividend-price yields) discourage new issues. About one-third of the residual error is accounted for by large single issues in the first halves of 1961, 1964, and 1966.

\section{SHORT-TERM LIQUIDITY RESERVE}

In contrast with the long-term finance equations, both liquid assets and short-term debt are dominated by variations in the external deficit of the 
current period. The longer-term movements are related to net financial liabilities as the best single scale measure of desired liquidity. Thus both types of financing display a buffer stock adjustment to variations in the external deficit and cushion bond and stock financing needs against much of the short-run variation in the total deficit.

The impact of the current deficit is slightly smaller in the debt equation, as would be expected since debt is a less immediate source of funds. Loans did not appear to respond to variations in unpaid tax liabilities, and internal funds were insignificant as a measure of short-term debt capacity. However, loans do show a strong response to corporate stock retirements. Interest rate substitution appears to play an important role with strong offsetting responses between liquid assets and short-term debt. Because of collinearity between the rates, it is not possible to include a separate measure of the bank loan rate. Since the long rate carries a negative sign in the borrowing equation, the results imply that the effective loan rate is close to the measured long-term rate and that the primary form of substitution is between increased loans and reduced liquid assets rather than between short- and long-term debt.

In examining the equation for liquid assets, it must be borne in mind that their volume is largely a residual outcome of specific decisions with regard to the other three financing sources. Thus, if it were not for the residual unallocated items, the form of this equation could be inferred from the coefficients of the other three equations. However, there is some interest in a direct estimate of the equation itself since it shows clearly the role of liquid assets as a buffer against changes in the deficit and unpaid tax liabilities, as well as its role as a substitute for short-term debt in the overall liquidity reserve.

The residual nature of liquid assets implies that a complete specification should include all the terms that appear in the other equations. But such a procedure would involve too many variables and a serious shortage in the degrees of freedom. The specification used therefore includes only the subset of variables that have the largest and most significant influence.

\section{OVERALL EVALUATION}

The equations display only minor discrepancies when evaluated in terms of the overall flow and adjustment constraints that should apply. The sum of the coefficients for the external deficit is greater than 1 and that for unpaid tax liabilities is substantially smaller than expected, but both of these 
results were confirmed by a direct estimate of the residual items of net trade credit, statistical discrepancy, and miscellaneous unallocated liabilities. These items do show a modest inverse correlation with the deficit.

An effort was made to include the lagged stock of the competing financial items in each of the equations, but they were insignificant. This is not surprising, since each of the items is itself a component of the accumulated external deficit. The results imply a net positive impact of interest rates on the residual items of the financial balance sheet, an implication confirmed by a direct estimate of that category. The primary reason for this outcome is that both net trade debt and the unallocated items increase slightly during periods of tight money. The dividend-price yield is not included in any of the financial equations other than that for stock issues because of its low significance. However, in these equations the sign of the coefficient was positive, implying a substantial offset to the negative influence found for corporate stock, rather than a negative correlation between the residual items and new stock issues. ${ }^{6}$

An additional evaluation of the equations was obtained by correlating the residual errors for the individual equations with one another. A significant degree of error offset was found for liquid assets and short-term credit, but not for the other two sources of funds. The errors in the liquid assets and short-term borrowing equations are also correlated with the residual category. This result is consistent with the view that inconsistencies in measurement error among data sources are most severe for shortterm changes, the exclusion of an accurate measure of net trade credit for the deficit measure, and the lack of a strong prior specification for the shortterm choice between bank debt and liquid assets as components of the liquidity reserve.

Finally, the residual category was added as an independent variable to the four equations to see if its inclusion would alter the results. While substantially lowering the overall error of the two liquidity equations, it in no

6. With respect to the major independent variables the individual equations are quite consistent with one another. This suggests that it might be useful to reestimate the equations by constrained regression where the overall balance sheet restrictions are taken directly into account. This was not done in the present case since such a precise estimate of the overall structure was not really necessary for the issues that I wished to examine. In addition such a procedure makes it more difficult to evaluate the role of the independent variables in individual equations. It is clear that such a technique would not affect the basic conclusions. 
case changed the coefficients by a significant amount; in fact, it changed the interest rate terms only trivially.

Several other variables were tried in the equation without success. The rate of inflation was found to be unimportant in the choice between equity and debt issues, and the corporate tax rate was not a significant variable in determining the stock of debt (perhaps because of very limited variation over the data period). Alternative measures of short-term rates do not influence the results, but the Baa rate does perform better than alternative long-term rates (apparently because of its greater cyclical variability relative to rates such as the Aaa bond yield). While the introduction of certificates of deposit substantially altered the composition of liquid assets, there was no evidence that either the creation of this type of time deposit or its rate has influenced the total stock of liquid assets. Finally, the external deficit was disaggregated into various components to see whether individual types of borrowing were tied to specific expenditures. This procedure did not improve the fit of the equations. As might be anticipated, the tendency seems to be to make financial decisions in terms of overall borrowing needs.

\section{Bank Rationing}

It has been suggested in the past that variations in the terms of bank loan contracts other than interest rates (that is, compensating balance requirements, loan maturities, credit ratings, and acceptability of new customers) may be an important element of bank lending policies. The notion is that the interest rate by itself is not an appropriate measure of lending costs and empirical studies that focus solely on it ignore a major potential source of monetary restraint. One result of the previous equations was the inability to find a role for the bank rate in determining the composition of the financial balance sheet. Attempts were made to add several measures of credit tightness to the equations, but without success. These measures included current and past levels of free reserves and a measure of excess loan capacity:

These results need not suggest that nonrate factors are unimportant elements of the loan contract. The more important issue is whether they have been altered in a cyclical fashion that does not correspond to changes in rates. If variations in nonrate terms are roughly proportionate to changes in interest rates, the use of rates alone does not imply a serious bias in the measure of credit restraint. 
On the other hand, the rapid growth of nonbank short-term credit in recent years is suggestive of a shortage of bank credit relative to the historical trend. This implication can be examined in somewhat greater detail in terms of the mix of short-term credit between bank and nonbank loans. In particular, an attempt can be made to explain the rise in short-term nonbank debt.

The best equation is similar in structure to the earlier equations. The growth of nonbank finance $(O S L)$ is related to (a) the difference between the commercial paper rate $(R C P)$ and that for bank loans $(R B L)$ and (b) the total external deficit:

$$
\begin{aligned}
& \Delta O S L=[0.0285 R B L-0.0147 R C P+0.0015 \text { time }-0.2020] S L \\
& \text { (8.0) } \\
& \text { (5.4) }
\end{aligned}
$$

The results show a very pronounced substitution corresponding to variations in relative interest rates, and a tendency for nonbank credit to be a more common form of financing during periods of cyclical increases in the size of the external deficit. The next step was to add several measures of the tightness of credit conditions to the equations as a proxy for credit rationing. Both free reserves and the measure of excess loan capacity were very insignificant. The latter measure was constructed as the total amount of deposits that could be supported by existing unborrowed reserves less the previous period's stock of bank loans, consumer credit, and mortgages. Another measure, the ratio of bank loans to total deposits, was equally insignificant. Nor is there any clear pattern in the residuals during generally recognized periods of tight credit conditions.

It seems doubtful that nonrate rationing has had a major impact on the distribution of credit, except as it may have paralleled movements in rates. What differentiates this analysis from previous more detailed studies is its specific recognition that banks are primarily price setters and quantity takers in the loan market in contrast to their operations in federal government securities and state and local government bonds. Therefore, an accurate specification of the quantity fluctuations in loans should be oriented toward the financial structure of firms rather than that of banks. The residual variation resulting from this specification does not show a significant correlation with the bank portfolio structure. 
On the other hand, it must be emphasized that the results here do not imply that nonrate factors are unimportant; they imply only that nonrate factors have been altered commensurately with the rate itself. The equation does not imply that bank lending is a simple function of the interest differential. At the margin, a 1 percentage point rise in the bank rate has nearly twice the effect on the volume of bank loans as a 1 percentage point drop in the commercial paper rate. This differential behavior is the result presumably of associated changes in the nonrate terms:

\section{Recent Developments in the Bond Market}

The bond equation offers insight into the sharp expansion of bond issues in recent years. Table 3 shows the contributions of the major determinants of bond financing since 1965 . The largest single influence has been the tremendous increase in the basic demand for financing that came

\section{Table 3. Sources of Expansion in the Corporate Bond Market,}

\section{Semiannually, 1966-72}

Billions of dollars

\begin{tabular}{|c|c|c|c|c|c|c|}
\hline \multirow[b]{2}{*}{$\begin{array}{c}\text { Year } \\
\text { and half }\end{array}$} & \multirow[b]{2}{*}{$\begin{array}{c}\text { (1) } \\
\text { Actual }\end{array}$} & \multirow[b]{2}{*}{$\begin{array}{c}(2) \\
\text { Predicted }\end{array}$} & \multicolumn{3}{|c|}{ Contribution } & \multirow[b]{2}{*}{$\begin{array}{c}\text { (6) } \\
\text { Residual } \\
\text { error }\end{array}$} \\
\hline & & & $\begin{array}{c}\text { (3) } \\
\text { Basic } \\
\text { demanda }\end{array}$ & $\begin{array}{c}(4) \\
\text { Interest } \\
\text { rate }\end{array}$ & $\begin{array}{c}(5) \\
\text { Stock } \\
\text { retirements }\end{array}$ & \\
\hline 1966 First & 5.5 & 4.8 & 4.2 & -0.2 & 0.8 & 0.7 \\
\hline Second & 4.8 & 4.9 & 5.1 & -0.6 & 0.4 & -0.1 \\
\hline 1967 First & 6.7 & 7.3 & 7.2 & -0.4 & 0.5 & -0.6 \\
\hline Second & 8.0 & 7.4 & 7.3 & -0.3 & 0.4 & 0.6 \\
\hline 1968 First & 6.1 & 6.5 & 6.3 & -0.8 & 1.0 & -0.4 \\
\hline Second & 6.8 & 7.0 & 6.4 & -1.1 & 1.7 & -0.2 \\
\hline 1969 First & 6.7 & 6.4 & 6.7 & -1.7 & 1.4 & 0.4 \\
\hline Second & 5.3 & 5.8 & 8.6 & -2.8 & 0.0 & -0.5 \\
\hline 1970 First & 9.2 & 8.7 & 12.0 & -3.5 & 0.2 & 0.4 \\
\hline Second & 11.0 & 11.0 & 13.7 & -2.9 & 0.2 & 0.0 \\
\hline 1971 First & $12.7^{\mathrm{b}}$ & 13.1 & 13.9 & -1.0 & 0.2 & -0.4 \\
\hline \multicolumn{7}{|l|}{ Projection } \\
\hline 1971 Second & $\ldots$ & 12.3 & 13.5 & -1.4 & 0.2 & $\cdots$ \\
\hline 1972 First & ... & 11.5 & 13.1 & -1.8 & 0.2 & $\ldots$ \\
\hline Second & $\ldots$ & 11.0 & 12.6 & -1.8 & 0.2 & $\ldots$ \\
\hline
\end{tabular}

Source: Calculated from bond equation of Table 2 and unpublished data from the Federal Reserve System. Interest rate impact is measured as deviation from the 4 percent rate in effect in 1965:2.

a. The measure of the basic demand is the total value of those elements of the bond equation other than interest rates and stock retirements. It is equal to column (2) minus columns (4) and (5).

b. Preliminary. 
from the growth of the external deficit since 1965 and the delay in adjusting bond issues to it, as measured by the lagged stock term. Thus the basic underlying demand for bond financing, shown in column (3), rose from a $\$ 5$ billion semiannual rate in 1966 to $\$ 14$ billion by early 1971 . The pattern of bond issues was seriously distorted between 1968 and 1969 by stock conversions associated with mergers. This factor is responsible in large part for the decline in bond issues in the second half of 1969.

The cyclical fluctuations in interest rates also had an impact on the timing of the bond issues. The sharp rise of interest rates in 1969 lowered bond issues in 1969 and the first half of 1970 by a total of nearly $\$ 5$ billion from the 1968 rate. On the other hand, the drop in interest rates in 1970 and 1971 raised bond issues in the first half of 1971 \$2.5 billion above their level of a year earlier. The effects shown in the table do not represent the full effects of an interest rate change since no account has been taken of the delayed impact as represented by the lagged stock. But the essentially shortrun orientation of these equations without a reliable measure of expected or normal rates (other than the trend term) suggests that such equilibrium calculations would not be reliable. The lower existing stock of bonds resulting from the high interest rates of the 1969-70 period, however, did have a significant positive influence on bond issues in the first half of 1971.

The equation can also be used to examine the anticipated pattern of bond financing in the near future. Is the current high level of new issues likely to continue or is it a temporary phenomenon? The projection shown in Table 3 is based on a roughly parallel growth in retained earnings and capital expenditures after the middle of 1971 and a Treasury bill rate stable at 5 percent. This would imply a mild decline in bond issues to an annual rate of about $\$ 23$ billion over the next eighteen months.

However, the crucial question for bond issues further in the future revolves around the components of the basic external deficit. With a recovery of corporate profits in early 1971, a leveling of capital expenditures, and increased availability of mortgage financing, the deficit has already been reduced from its $\$ 12$ billion peak in late 1969 to $\$ 8$ billion for the first half of 1971. This improvement has been less than that during previous periods of major changes in the deficit, for a variety of reasons. Firms did not experience the usual sharp cyclical swings in inventory accumulation; the current economic expansion has been of more modest proportions than those in the past, with a resulting slower recovery of profits; and the potential gains were held down in the first half of 1971 by a substantial increase in direct 
foreign investment. Profit margins remain very low by historical standards; and an accelerating rate of economic expansion, together with the two business tax proposals of the administration, could substantially improve the flow of retained earnings. However, these tax measures would have a more immediate impact on short-term credit needs since the smaller deficit is partially offset in the bond equation by an implied rise in debt capacity as a result of a higher cash flow.

The question of future trends in bond financing can also be examined in terms of corporate liquidity requirements. It has been alleged that corporations have been critically short of liquidity in recent years and that the time of the Penn Central receivership marked a transition to a period of sharply increased bond issues as a means of restoring liquidity. But it is interesting to note that the equations, which do not have any specific adjustment for this period, also do not have unusually large errors in the two periods following the Penn Central receivership.

One common measure of liquidity - the ratio of liquid assets and shortterm debt to sales-is shown in Table 4. While there has been a drop in liquid assets and a rise in debt relative to sales, compared with the early 1960 s, the results are not alarming when viewed against the normal cyclical patterns and trends in these ratios.

The liquid asset ratio has a very strong downward trend that is acceler-

\section{Table 4. Liquidity Ratios for Nonfinancial Corporations, Cyclical Peaks} and Troughs, 1955-71

\begin{tabular}{lccc}
\hline Year and half & $\begin{array}{c}\text { Ratio of } \\
\text { liquid assets } \\
\text { to sales }\end{array}$ & $\begin{array}{c}\text { Ratio of } \\
\text { short-term } \\
\text { debt to sales }\end{array}$ & $\begin{array}{c}\text { Net } \\
\text { difference }\end{array}$ \\
\hline 1955 First & 0.558 & 0.235 & 0.323 \\
1957 Second & 0.467 & 0.287 & 0.180 \\
1959 First & 0.509 & 0.276 & 0.233 \\
1963 Second & 0.498 & 0.300 & 0.198 \\
1967 First & 0.398 & 0.373 & 0.025 \\
1968 First & 0.417 & 0.377 & 0.040 \\
1969 Second & 0.416 & 0.443 & -0.027 \\
1970 First & 0.434 & 0.455 & -0.021 \\
1970 Second & 0.435 & 0.452 & -0.017 \\
1971 First & 0.443 & 0.435 & 0.008 \\
\hline
\end{tabular}

Source: Same as Table 2.

a. Liquidity ratios are constructed relative to a moving average of final sales for nonfinancial corporations (gross product minus inventory accumulation) with weights of 0.6 and 0.4 on the current and previous periods, respectively. 
ated during the late stages of a business cycle. Low long-term interest rates and the strong growth of internal funds slowed this decline substantially in the early 1960 s, so that the drop of recent years looks particularly dramatic. However, the decline in the ratio from its peak in 1963 to 1967 is no more severe than that of 1955 to 1957 , and the ratio has actually increased slightly in recent years.

Much of the same type of cyclical pattern is observed for bank loans about a generally rising long-term trend. Although it could be claimed that the long-term trend in these ratios cannot continue forever, it is difficult to find that their recent cyclical behavior has differed significantly from past periods such as 1957-58. Even the net excess of liquid assets over short-term debt provides no evidence of a substantial deterioration in liquidity since 1967. Rather, the major differentiating factor relative to past cycles is the lack of a strong business expansion that could reduce the external deficit through increased earnings. In addition, no clear pattern emerges in the residual errors of the two liquidity equations in recent years that would suggest a consistent tendency either to over- or underpredict the actual values.

The conclusion, therefore, is that the present high levels of new bond issues are primarily the result of an unusually high external deficit. Some of the recent upsurge can be attributed to a postponing of bond issues in the previous tight money periods, but neither the Penn Central receivership nor a sudden liquidity crisis has had a major impact on the total volume of financing. The decline in corporate liquidity does not appear overly severe when viewed against longer-term trends and the normal cyclical response of liquidity to variations in total financial requirements and in interest rates.

\section{IMPLICATION FOR THE CAPITAL MARKETS}

The previous results might raise some questions about whether the continued high level of new bond issues will cause serious problems for the capital markets. In this regard it is useful to look back at the developments of recent years to see how the sharp rise in bond issues was absorbed in the market (see Table 5).

The postwar bond market prior to 1966 was dominated on the demand side by institutional investors-insurance companies and pension funds. These investors viewed bonds as an attractive form of investment and absorbed 85 percent of the total increase in outstandings in the 1955-65 period, primarily in the form of private placements. 
Table 5. Supply and Demand of Corporate and Foreign Bonds, 1961-71

Billions of dollars, annual rate

\begin{tabular}{lrrrrr}
\hline $\begin{array}{l}\text { Issuer, purchaser, and } \\
\text { other data }\end{array}$ & $1961-65$ & $1966-70$ & 1969 & 1970 & $\begin{array}{c}1971, \\
\text { first half }\end{array}$ \\
\hline Net issues & 7.0 & 16.5 & 14.8 & 23.7 & 31.3 \\
Nonfinancial corporations & 4.5 & 14.0 & 12.1 & 20.3 & 25.3 \\
Other & 2.5 & 2.5 & 2.7 & 3.4 & 6.0 \\
Purchasers & & & & & \\
Insurance and pension funds & 6.2 & 7.7 & 5.9 & 8.2 & 9.4 \\
Mutual savings banks & -0.2 & 1.1 & 0.3 & 1.4 & 7.2 \\
Households & 0.2 & 5.7 & 5.4 & 12.2 & 12.7 \\
Other & 0.8 & 2.0 & 3.2 & 1.9 & 2.0 \\
Increase in assets of mutual & & & & & \\
$\quad$ savings banks & 3.5 & 4.1 & 3.1 & 4.7 & 12.8 \\
Household purchases & & & & & \\
All financial assets & 42.1 & 60.4 & 55.2 & 70.6 & 96.5 \\
Deposits & 27.5 & 32.2 & 19.2 & 36.9 & 93.2 \\
Marketable securities & 2.0 & 9.3 & 18.4 & 10.5 & -25.2 \\
Other financial assets & 12.6 & 18.9 & 17.6 & 23.2 & 28.5 \\
\hline
\end{tabular}

Source: Same as Table 1.

Since 1965, however, two major changes in the structure of the market have occurred. First, in the first half of 1971, the growth in bond holdings of insurance and pension funds absorbed only a third of total issues. Second, the experiences of 1966 and 1969 demonstrated that insurance companies, like depository institutions, could also suffer substantial reserve losses through policy loans. The result was an increased concern with liquidity and reduced interest in nonmarketable private placements.

Thus, the accelerating volume of corporate bond issues was concentrated in public offerings and purchased primarily by two sectors-households and mutual savings banks. A major portion of this higher rate of purchase by these institutions has been at the expense of the mortgage market. In the 1960-65 period, the increase in mortgage holdings of savings banks equaled the growth in total assets, and corporate bond holdings actually declined slightly. In the following five years, however, corporate bonds accounted for one-fourth and mortgage loans for only two-thirds of total asset growth.

The shift in the composition of savings bank portfolios was particularly evident in the first half of 1971 when deposit inflows into all of the deposit institutions accelerated far faster than any possible expansion of mortgage lending. The savings banks, which are not as restricted as savings and loans 
and commercial banks in their portfolio composition, channeled most of this sudden inflow of funds into the corporate bond market, establishing an annual rate of net purchase of $\$ 7.2$ billion versus $\$ 1.4$ billion in 1970 .

However, this rate of bond purchase by savings banks can hardly be viewed as a stable long-run situation. Deposit inflows at savings banks were at an unsustainable annual rate of $\$ 12$ billion in the first half of 1971, compared with an average of $\$ 3.5$ billion in the 1961-70 period. These deposit inflows will taper off as interest rate differentials begin to stabilize after the roller coaster experience of 1969-71 and households complete the realignment of their financial portfolios. Bond purchases by these institutions are likely to decline in a similar fashion.

The household sector has been the primary source of increased demand for corporate bonds. Over the last five years this growth has been associated with expanded holdings of all marketable securities relative to deposit accounts. It has been accomplished by driving up market yields relative to the rates paid on deposit accounts, which are constrained by interest rate ceilings.

Since the deposit account institutions dominate the market for mortgage lending, the overall outcome has been one of a substitution of corporate bonds for mortgage loans. However, not all of the growth in the bond market has been at the expense of mortgage lending. The extent to which increased business borrowing has been financed by higher consumer savings rates is not negligible. Thus, there has been a substantial growth in household demand for all types of financial assets rather than a simple substitution of bonds for deposits at mortgage lending institutions.

Households continued to purchase large amounts of corporate securities in the first half of 1971 despite a sharp shift out of other marketable securities into deposit accounts. This shift was primarily the result of developments in other sectors. First, the lifting of the restrictions on the rates deposit institutions could pay, in early 1970, substantially improved their ability to attract funds as market rates retreated from their 1969 peaks. Second, there was a major increase in the demand for marketable securities on the part of commercial banks and corporations. The pronounced easing of monetary policy, together with reduced business loan demand, led commercial banks to reenter the market as large net purchasers. Corporations responded to the moderation of capital expenditures and the improved flow of internal funds with an attempt to build their stock of liquid assets. This increased demand for marketable securities did not have a proportionate 
impact on the demand for corporate bonds because of the strong preference of the two sectors for the liquidity of government securities and the taxexempt status of municipals.

Furthermore, much of the shift of funds back to the deposit institutions was reflected initially as a simple transfer of marketable securities between households and the institutions, and as reduced lending by federal agencies in support of the mortgage market. In the short run, mortgage lending cannot respond fully to sharp variations in the deposit inflows of the financial intermediaries. Since only savings banks find corporate bonds a feasible form in which to invest the excess deposit inflow, the short-run impact is a sharp reallocation of government securities between households and deposit institutions.

Thus, the bond market is supported in the first instance by a basic component of demand, originating in the insurance and pension funds, that expands at a stable long-term rate. Any excess of bond issues above the amount absorbed by these institutions must be pushed off into the household sector. This residual component is unlikely to diminish significantly in the near future, despite the growth in the insurance sector and some gradual reduction in overall issues, because the current high rate of purchases by savings banks is likely to be of a temporary nature.

These results seem to imply that long-term bond rates will have to continue to maintain a significant yield advantage over rates offered by the depository institutions if the household sector is to be induced to absorb the excess bond issues. However, this inducement need not result in a major reduction in mortgage funds in view of the current high levels of liquidity enjoyed by the mortgage lending institutions. 


\section{Comments and Discussion}

Warren Smith: In essence Barry Bosworth has devised a model of corporate debt management. It takes as given the deficit to be financed by the corporate nonfinancial sector, defining it as the excess of capital outlays over gross internal funds, adjusted for consumer credit extensions and the change in mortage liabilities. This deficit has to be covered by some combination of short-term borrowing from banks, from finance companies, and in the open market; bond issues; stock issues; adjustments of liquid assets; and changes in miscellaneous liabilities. According to Walras' law, independent decisions can be made with respect to four of these five elements, while the fifth takes on the value needed to match the deficit. Treating interest rates as exogenous and viewing the nonfinancial corporate sector as concerned about its liquidity, safety, financial flexibility, and the maintenance of a balanced capital structure, Bosworth estimates stock adjustment type equations that explain bond issues, stock issues, short-term debt, and liquid assets. There is some ambiguity about whether he views these as four independent equations with miscellaneous liabilities as the residual or whether he regards one of the four as a dependent equation that is included along with miscellaneous liabilities in the residual.

The model yields very good results and not many surprises. The features that especially interest me are the interest rate coefficients in the bond and short-term debt equations. The bill rate is the only interest rate that appears in the bond equation, and it carries a negative coefficient. The bill rate appears with a positive coefficient and the bond rate with a negative 
coefficient in the short-term debt equation, suggesting (approximately) that when the bill rate is high relative to the bond rate, short-term borrowing is encouraged. At first glance this seems a strange result-high short-term rates encourage short-term borrowing and discourage long-term borrowing, while low long-term rates encourage short-term rather than long-term borrowing. However, if one views interest rate expectations as basically regressive, these results are quite reasonable. When short-term rates are above long-term rates, for example, as in 1969 , this is commonly taken as a sign that long-term rates will fall and that it is preferable to borrow at short term temporarily in anticipation of the decline. Conversely, the best time to borrow at long term is when long-term rates are low even though at such times short-term rates are commonly lower still. Thus, the signs of the coefficients in these equations may be taken as further evidence that expectations are predominantly regressive. On the other hand, I am a bit surprised at the positive sign of the short-term rate coefficient and the negative sign for the bond rate in the liquid assets equation, since I would have expected to find that when the short rate is high relative to the long, sales of liquid assets (or at least a slowdown in their accumulation) would occur.

There is one point I would like to mention although I don't know how important it is or what can be done about it. The burden on the corporate bond market would be better measured by gross new issues rather than by the net change in the stock. The difference is substantial-in 1970 for the entire corporate sector, new issues of bonds and notes amounted to $\$ 29.5$ billion, while the change in the stock was $\$ 22.8$ billion, the difference representing $\$ 6.7$ billion of retirements. The retirement of debt, most of which has a zero maturity, financed by new issues of long-term bonds, may well have a substantial effect on market conditions, although probably not as much as does the refunding of Treasury debt because corporate debt is more likely to remain in the hands of long-term investors until maturity. Nevertheless, this suggests the desirability, if possible, of adding retiring debt to the deficit and treating it as part of total requirements to be financed. Perhaps this would not be feasible-the existence of call provisions would be a complication at times-but it is worth considering.

This study brings out the relative unimportance of new equity financing as a source of funds. It should perhaps be pointed out that retention of earnings is a form of equity financing, which makes it unnecessary to sell much stock in order to maintain a balanced capital structure. 
The study also brings out very neatly the fact that, if the deficit is taken as given, liquidity, whether in the form of more liquid assets or more unused debt capacity, can be increased only at the cost of additional longterm debt. In his interpretation of developments with respect to corporate liquidity, as presented in Table 4, however, I thought Bosworth went out of his way to minimize the significance of the quite startling deterioration. I am not given to worrying about such matters, but the trend shown in the table does strike me as quite remarkable.

Finally, I would point out that the fact that interest rates apparently capture the effects of nonrate rationing of bank credit-a result that doesn't surprise me--does not mean, as Bosworth says it does, that nonrate rationing has not had a major impact on the distribution of credit.

Daniel Brill: It is encouraging, for a change, to find an empirical study in this area that does not shatter all preconceptions. The interesting problem comes in explaining the sequence of financing from liquid assets, used as an initial buffer stock, into the undertaking of long-term debt. What factors influence that decision? Bosworth indicates that interest rates play only a small part. I think balance sheet structure is an important consideration in making that decision and that it is only partially captured in Bosworth's highly aggregated formulation.

The decision for long-term financing is not taken lightly. It is usually postponed, particularly in the periods when the corporate deficit is increasing, because that is usually the time when borrowing costs in the long-term capital markets are rising. What eventually forces the decision to enter the long-term bond market? I think the answer might be established more clearly by a study of balance sheet ratios and the influence these ratios have both on corporate treasurers and on lenders and rating agencies.

Bosworth alludes to this influence of balance sheet position. However, I do not see it tested adequately, given my assumption that this is an important factor determining the timing of the firm's entry into the bond market.

I agree with Warren Smith that the deterioration of liquidity probably should have shown up more strongly as a variable influencing recent financial behavior. I am surprised that Bosworth's findings do not reveal a greater quantitative importance of the need to rebuild liquidity in explaining the volume of new corporate issues.

The one surprise in Bosworth's results is that nonprice rationing seems to have no cyclical deviation from cyclical changes in interest rates on bank 
loans. It would have been helpful to discuss what the influence of nonprice rationing might be, even if it does parallel the cyclical movement of interest rates. It would be particularly important to understand this influence if there is any attempt to disaggregate financing behavior within the nonfinancial sector.

Barry Bosworth: I did experiment in the bond equation with using the volume of new issues in place of the net change in outstanding bonds. It makes a difference in the case of equities because of the recent merger activity during which debt issues were used to finance the retirement of equities. But new bond issues correlate closely with net changes in the stock of bonds outstanding because bond retirements are very smooth. The use of a new issue series increases the scale of the numbers, but does not seem to affect cyclical patterns or any of the conclusions.

I am not as puzzled as Warren Smith by the signs of the interest coefficients in the liquid asset equation. A high asset yield (Treasury bill rate) relative to the cost of borrowing (bond rate) should encourage the holding of liquid assets. While it is true that liquid assets are low during periods of tight money such as 1969 , this situation results from changes in the basic external deficit and the high level of long- rather than short-term rates. However, I am more puzzled by the fact that the negative coefficient on the bill rate is so large. As a result, the net influence of interest rates is not zero when the liquid asset equation is subtracted from the borrowing equations. This result, together with problems of defining an expected future interest rate, argues against putting too much emphasis on the specific point estimates on the interest rate coefficients.

\section{General Discussion}

Saul Hymans suggested that, since the four types of financing analyses by Bosworth involve only three independent decisions, it might be useful to compare the predicted values of the liquidity equation with the values implied by subtracting the sum of the predictions of the three debt equations from the total deficit. This would provide a test of the internal consistency of the equations. David Fand asked if the bond rate would have a more important role if the data were divided into subperiods, and Bosworth replied that he had divided the data and found that the long-term interest rate still did not have a significant coefficient in the bond equation. 
Franco Modigliani reported on some of his own work relating a firm's desired stock of bonds to the total market value of the firm rather than its cumulated deficit. Within such a framework, inflation increases bond financing by raising the market value of the firm. Craig Swan asked about the interpretation of the coefficient for the cumulative deficit in the liquid asset equation. Since the reported coefficient is negative, it seemed to imply that an increase in the cumulative deficit would lead to a permanent reduction in liquid assets. Bosworth explained that since the cumulative deficit was used as a scaling factor for both interest rates and the time trend, the total effect of a change included the effects predicted from these terms. At present values of interest rates and the time trend, these other terms offset the negative coefficient on the deficit term alone, and thus predict an increase in liquid asset holdings as the cumulative deficit expands.

Arthur Okun expressed surprise that the results did not imply that current bond financing was abnormally high. He observed that many analysts thought special factors were important in explaining the high load of bond offerings in recent quarters, stressing the importance of the Penn Central bankruptcy and the experience with tight money as factors causing firms to seek greater liquidity through bond issues than they otherwise would have. Brill thought that the influence of Penn Central might be pronounced for some industries if the analysis were conducted on a disaggregated basis, even if it did not show up in Bosworth's aggregated study.

George Perry found the coefficient on retained earnings in the bond equation surprisingly large, if it was to be interpreted as a measure of debt capacity. Bosworth agreed and felt that it was probably picking up some purely cyclical timing elements in the decision to enter the bond market. 